\title{
The Effects of Fall Urea Sprays on the Leaf Size and Nitrogen Level of Spur Leaves in Sweet Cherry (Prunus avium)
}

\author{
Hemin Jalil MUSTAFA ${ }^{1}$, Semih ÇAĞLAR ${ }^{2}$ \\ ${ }^{1}$ KSU, Graduate School of Natural and Applied Sci., Dept. of Bioengineering and Science, Kahramanmaras/Turkey \\ ${ }^{2}$ KSU, Faculty of Agriculture, Department of Horticulture, Kahramanmaras/Turkey
}

Received (Geliş): 16.07.2014

Accepted (Kabul): 05.01.2016

\begin{abstract}
The aim of this study was to determine the effects of low biuret urea applied seven days apart in mid fall on the size and $\mathrm{N}$ level of spur leaves in 0900 Ziraat sweet cherry cultivar. In this experiment two doses of urea were used (62.5 g and $32.5 \mathrm{~g}$ urea /tree) and control trees were also included as a third treatment. The size of spur and shoot leaves was positively affected by urea sprays: the spur and shoot leaf size were increased more than twice compared to those of the control trees. The $\mathrm{N}$ level in the spur leaves were also increased by the urea sprays. The fall low biuret urea spray to 0900 Ziraat sweet cherry trees was considered to be an efficient tool for increasing the size of spur leaves, leaading to better sized fruits.
\end{abstract}

Key Words: Plant nutrition, low biuret, nitrogen, fruit size, Prunus avium

\section{Kirazda Sonbahar Üre Püskürtmesinin Spur Yaprakların Büyüklüğü ve Azot Düzeyi Üzerine Etkisi}

ÖZET: Bu çalışmada 0900 Ziraat çeşidi kiraz ağaçlarına sonbahar ortasında yedi gün aralıkla iki kez püskürtülen düşük biüretli ürenin spur (mayıs buketi) yapraklarının büyüklüğüne ve azot içeriğine olan etkisi incelenmiştir. Denemede uygulama olarak ağaç başına $32.5 \mathrm{~g}$ ve $62.5 \mathrm{~g}$ olmak üzere iki üre dozu püskürtülmüş olup ayrıca tanık ağaçlar da yer almıştır Spur ve sürgün yapraklarının iriliği sonbahar üre uygulamasından olumlu etkilenerek tanık ağaçlarınkine gore en az iki kat daha fazla olmuştur. Üre uygulaması ilkbaharda spur yaprakların $\mathrm{N}$ içeriğini de arttırmıştır. Sonbaharda yapraktan düşük biüretli üre uygulamasının 0900 Ziraat çeşidi kiraz ağaçlarının spur yapraklarının iriliğinde artış sağladığı ve böylece meyvelerin de iriliğine olumlu etki sağlayabilecek etkili bir uygulama olduğu anlaşılmıştır.

Anahtar Kelimeler: Bitki besleme, düşük biüret, azot, meyve iriliği, Prunus avium

\section{INTRODUCTION}

Sweet cherry (Prunus avium L.) is an economically important fruit of the temperate zone. The world demand for high quality sweet cheery is increasing and the growers are earning good money. New cherry cultivars have been developing over the world, however, high quality cherry production areas are limited to certain climatic conditions. Good soils, a perfect climate and the fact that sweet cherries are native to the area of Asia Minor means that Turkey has perfect conditions to grow sweet cherries throughout the country (Long, 2006). Increased Turkish sweet cherry export is based on two factors: a high quality cultivar and proper postharvest processes (Çağlar, 2012). In the past, Germany, Italy, Spain and France have dominated the European market. However, in the last decade cherries from Turkey have captured an increasingly large market share. The vast majority of this fruit was a single variety called '0900 Ziraat', sometimes sold in Europe under the name 'Napoleon (Long, 2006). The fruit of this cultivar is large $(8.2 \mathrm{~g})$, mahogany colored with pink flesh, very firm, aromatic, juicy, crack resistant (Demirsoy ve Bilginer, 2000) and has long storage life. The flavor is excellent and has been readily accepted by European consumers.

Fruit size is a critical fruit quality trait, in which a difference of only $2 \mathrm{~mm}$ diameter for fresh market sweet cherries can make the financial difference between profit and loss. Although other fruit quality parameters are also important, adequate fruit size is absolutely essential ( Iezzoni, 2013). In Turkey the minimum sweet cherry fruit size for export is $26 \mathrm{~mm}$ in diameter. The fruits that are lower than $26 \mathrm{~mm}$ are not accepted by the exporters and be destined to local markets with lower prices. Bigger fruits $(>26 \mathrm{~mm})$ bring the farmers a premium price. Therefore the cultural practices is important for sweet cherry growers in order to obtain bigger fruits. Nitrogen fertilization timing appears to be important criteria for sweet cherry fruit sizing.

Ayala and Lang (2004) investigated carbohydrate reserves in sweet cherry and found that stored carbohydrates are used for the development of fruiting and non-fruiting spur leaves during the first few weeks after bud break. These spur leaves are important source for supporting the early growth of sweet cherry fruits.

Urea is a very economic form of nitrogen, but is vulnerable to losses from leaching and volatilisation. Nitrogen can be applied to horticultural crops by one of three methods: dry applied, fertigation or foliar applications. Of these, foliar nitrogen is least likely to impact on the environment. However, foliar applications of urea can carry a different set of problems, one of which is the impact of biuret. Biuret, also known as carbamyl urea, is a nitrogenous impurity that is formed in the manufacture of urea. It is thought that Biuret 
burns leaves - the first symptom of biuret toxicity is irregular patches of interveinal chlorosis (yellowing) appearing at the leaf tips. For foliar applications to biuret-sensitive crops, therefore, the use of low or ultralow biuret urea is recommended. The ultra-low biuret urea distributed by ballance contains less than $0.1 \%$ biuret (Anonymous, 2013).

Both pomolojist and fruit growers are not keen to nitrogen fertilization in the fall season. This is because nitrogen can stimulate vegetative growth in early fall and trees may become sensible to winter frost. However, a careful application of nitrogen (i.e, given a small portion of annual $\mathrm{N}$ demand) during the mid autumn can results a bigger achievement for improving fruit quality. Fall nitrogen application can be done by the use of urea. However, urea can burn leaves, because of the biuret it contains. Therefore, low biuret urea is strongly recommended for foliar $\mathrm{N}$ applicaiton (Anonymous, 2013). Although fall urea nitrogen application is a practice in some pome fruit trees, limited studies were conducted in stone fruits, including sweet cherries within certain cultivars (Ouzonis and Lang, 2011; Rothwell, 2012). The response of trees to nitrogen application depends on dose, timing as well as cultivar. In this study the well known Turkish export sweet cherry cultivar-0900 Ziraat was used as a plant material. The aim of this study was to determine the effects of two low biuret urea doses applied one week apart in mid fall on the size and $\mathrm{N}$ level of spur leaves of 0900 Ziraat sweet cherry cultivar.

\section{MATERIAL and METHODS}

In this study six years old sweet cherry trees (cv 0900 Ziraat) grown on mazzard seedling rootstock were used as plant material. The experimental sweet cherry orchard was located in the Kahramanmaraş Sutçü İmam Unıversity, Faculty of Agriculture, Department of Horticulture. The orchard was set up with a spacing of 5 x $2.5 \mathrm{~m}$. Trees were irrigated with micro sprinkler and grown under regular cultural practices.

In this experiment low biüret urea was used in foliar sprays. The biuret ratio was lower than $0.3 \%$ in the formulation (Nutribella Power Line- DRT). Dose selection was based on the previous recommendations (Rothwell, 2012) : $5 \mathrm{~kg}$ urea/da. Considering the trees number in an unit area (80 trees/da), in the first treatment a $62.5 \mathrm{~g}$ urea per tree was applied (Urea High). A half dose (32.5 g urea /tree) was also included as a second treatment (Urea Low). The experiment had also untreated trees applied only water (Control).

The low biuret urea application was made with two split applications. The first spray was made on 21 October of 2013 and repeated at 7 days later. Urea was sprayed trees by a knapsack sprayer and each tree receieved urea in 5 liters tap water. In this study spur leaf and shoot leaf area measurements were done at the pit hardening period on 40 spur or shoot leaves/tree with a digital planimeter (LI-3100 Model LICOR). The spur leaves were colleceted on 22 April 2014 and their Nitrogen status (\% of dry matter) was measured according to the Kjeldahl method using Kjeltec 8200 (Anonymous, 2012). In the experiment there were three replication per treatment and each replication consisted of three trees. Mean separation was done according to Duncan Multiple Range test (5\%) using Costat Package Program.

\section{RESULTS and DISCUSSION}

In this experiment, the nitrogen was sprayed to the sweet cherry trees in the form of low biuret urea with two split applications, first on 21st of October and second on 28th of October 2013. The effects of fall urea sprays on sweet cherry mean spur leaf size in subsequent spring (at the pit hardening period) have been shown in Table 1. The difference with regards to spur leaf area between both Urea treatments and control trees was statistically important. Both urea treatments increased the spur leaf area of sweet cherry trees. The spur leaf area was biggest with $37.69 \mathrm{~cm}^{2}$ in Urea Low treatment. The spur leaf area by Urea High treatment was statistically lower $\left(31.74 \mathrm{~cm}^{2}\right)$ than that of Urea Low treatment. The control trees had the smallest spur leaf surface area with $13.77 \mathrm{~cm}^{2}$. The spur leave size difference between urea treated trees and control trees was important. The spur leaf size was increased more than twice by the use of urea compared to that of control trees.

Table 1. The effects of fall urea sprays on sweet cherry spur leaf size during the pit hardening period of 2014

\begin{tabular}{lc}
\hline Treatments & Mean Spur Leaf Area $\left(\mathrm{cm}^{2}\right)$ \\
\hline Urea High & $31.74 \mathrm{~b}$ \\
Urea Low & $37.69 \mathrm{a}$ \\
Control & $13.77 \mathrm{c}$ \\
\hline LSD $(5 \%): 3.55$ & \\
\hline
\end{tabular}

The effects of fall urea sprays on sweet cherry mean shoot leaf size in subsequent spring can be seen in Table 2. The difference between both urea treatments and control trees with regards to shoot leaf size was stastically important. Both urea treatments increased the shoot leaf area of sweet cherry trees. Both urea treatments were in the same statistical group. The shoot leaf area was biggest with $93.56 \mathrm{~mm}^{2}$ in Urea High treatment, closely followed by Urea Low treatment $\left(86.30 \mathrm{~cm}^{2}\right)$. The control trees again had the smallest shoot leaf surface area with $38.47 \mathrm{~cm}^{2}$. Similar to spur leaf area, shoot leaf size in the sweet cherry was increased more than twice by the use of urea compared to the control trees.

In this experiment the sweet cherry spur leaf size was significantly increased by the use of low biuret urea compared to that of the non-treated trees. This result is in accordance with the studies of Ouzounis and Lang (2011) as well as of Mitre et al (2012). According to 
Ouzounis and Lang (2011) spur leaf size in the spring was associated with storage $\mathrm{N}$ levels; fall foliar urea treatments increased spur leaf area by up to $24 \%$. They stated that foliar urea applications inceased flower spur $\mathrm{N}$ levels most when applied in late summer to early fall.

Table 2. The effects of fall urea sprays on sweet cherry shoot leaf size during the pit hardening period of 2014

\begin{tabular}{lc}
\hline Treatments & Mean Shoot Leaf Area $\left(\mathrm{cm}^{2}\right)$ \\
\hline Urea High & $93.56 \mathrm{a}$ \\
Urea Low & $86.30 \mathrm{a}$ \\
Control & $38.47 \mathrm{~b}$ \\
\hline LSD (5 \%): 13.89 & \\
\hline
\end{tabular}

The effects of fall urea sprays on sweet cherry spur leaf nitrogen level in spring have been shown in Table 3. The Urea High treatment had highest $\mathrm{N}$ level with $3.05 \%$ while Urea Low treatment had $2.82 \%$, being in the same tastistical group. The spur leaves of control trees had the lowest $\mathrm{N}$ level with $2.43 \%$. The difference in spur leaf $\mathrm{N}$ levels between urea sprayed trees and control trees was stastistically significant. Previous works showed that the higher the leaf $\mathrm{N}$ content is the higher the leaf photosynthetic rate is (Evans, 1989). Therefore, leaf $\mathrm{N}$ content appears to be a major factor determining the photosynthetic rate per unit leaf area of the leaf (Faust, 1989). A good linear correlation has been obtained in peach and other stone fruit species between leaf $\mathrm{N}$ content and leaf photosynthesis rate (DeJong, 1982, 1983). It was reported that the higher leaf $\mathrm{N}$ content obtained by autumn urea sprays in sweet cherry could increase fruit weight and sugar content (Xu et al., 2007) which tranlates into the production of higher quality fruits.

Table 3. The effects of fall urea sprays on $\mathrm{N}$ levels of sweet cherry spur leaves colleceted on 22 April 2014

\begin{tabular}{lc}
\hline Treatments & Spur leaf nitrogen level (\% N of DM) \\
\hline Urea High & $3,05 \mathrm{a}$ \\
Urea Low & $2,82 \mathrm{a}$ \\
Control & $2.43 \mathrm{~b}$ \\
\hline LSD $(5 \%): 0.29$ & \\
\hline
\end{tabular}

\section{CONCLUSION}

The late season $\mathrm{N}$ spray is considered an important tool for improving $\mathrm{N}$ level of several fruit species. Because $\mathrm{N}$ uptake of fruit trees can be affected by absorbing organs (i.e. roots or leaves) in relation with application seasons. In a foliar urea study on young apple trees it was found that roots absorbed more $\mathrm{N}$ than leaves during July, and leaves absorbed more $\mathrm{N}$ than roots in the beginning of May; although leaf $\mathrm{N}$ uptake rate was similar in May and July, it was higher (60\% increase) in September (Dong et al., 2005).

The fall or dormant application of $\mathrm{N}$ appears also a very effective way in increasing fruit set, indicating the involvement of storage $\mathrm{N}$ in the fruit set (Tukey, 1952). Fall $\mathrm{N}$ application may also contributed to fruit set which was not investigated in this study. The $\mathrm{N}$ absorbed by leaves during senescence is highly mobile in fruit trees. The translocation of $\mathrm{N}$ from the leaves in fall may depend on temperature. If temperature is such that leaves senesce slowly, most of the $\mathrm{N}$ is translocated. However, $\mathrm{N}$ application in late fall also increases the rate of photosynthesis of leaves, and they stay green longer. This increases the possibility that they may be killed by frost before the $\mathrm{N}$ is translocated to the tree (Tukey, 1952). Therefore, spray timing seems to be an important crieteria for late season and should be determined with care. Spur leaves play an important role in sizing the fruits of sweet cherry. Ayala and Lang (2004, 2008) showed that spur leaves supplied the majority of the photosynthetic carbon for cherry fruit growth, and their development and expantion are limited to the first 3 to 4 weeks after budbreak, coinciding with the supply of $\mathrm{N}$ from remobilized storage reserves. Therefore to obtain bigger sized cherries, fall $\mathrm{N}$ application seems to be crucial.

From this study it appeared that fall nitrogen application to sweet cherry trees had positive efffects on the size of spur and shoot leaves as well as nitrogen levels of spur leaves. The application of low biuret urea in autumn just before leaf fall can be a valuable method for supplying additional $\mathrm{N}$ to sweet cherry trees, leading to better sized fruits.

\section{REFERENCES}

Anonymous, 2012. Determination of total nitrogen in food and crude protein calculation (Kjeldahl method) in Analysis of Food and Natural Products Laboratory exercise. Institute of Chemical Technology, Praque. http://web.vscht.cz/ kohoutkj/ENG/LAB_NITROG EN_Determination_2012.pdf. (Accessed at June, 2014.)

Anonymous, 2013. Grow Plus.-A Horticultural Newsletter From Ballance Agri-Nutrient Limited. Issue 1. http://www.ballance.co.nz/uploads/ publications/growplus\%20issue $\% 201 \% 20$ web.pdf. (Accessed at: May, 2014).

Ayala, M., Lang, G.A. 2004. Examining the Influence of Different Leaf Populations on Sweet Cherry Fruit Quality. Acta Hort. 636: 481-488.

Ayala, M., Lang, G.A. 2008. 13C-Photoassimilate Partitioning in Sweet Cherry on Dwarfing Rootstocks During Fruit Development. Acta Hort. 795: 625-632.

Caglar, S. 2012. Turkish Sweet Cherry Export Relies on the Combination of a High Quality Cultivar and Proper Postharvest Techniques. Southeast Asia Symposium on Quality Management in Postharvest Systems. 21-24 February, 2012. Bangkok, Thailand 
DeJong, T.M. 1982. Leaf nitrogen content and CO2 assimilation capacity in peach. J. Amer. Soc. Hort. Sci. 107: 955-959.

DeJong, T.N. 1983. CO2 assimilation characteristics of five Prunus tree fruit species. J. Amer. Soc. Hort. Sci. 108: 303-307.

Demirsoy, L., Bilgener, Ş. 2000. Meyve Çatlamasına Hassasiyet Bakımından Bazı Kiraz Çeşitlerinin Kütikülar ve Epidermal Özellikleri Üzerine Kimyasal Uygulamalarının Etkileri. T.J. Agric. For. (24): 541-550.

Dong, S. L., Cheng, C.F. Seagel, Fuchigami, L.H. 2005. Timing of urea application affects leaf and root $\mathrm{N}$ uptake in young Fuji/M9 apple trees. J. Hortic. Sci. and Biotech. 80: 116-120.

Evans, J.R., 1989. Photosynthesis and nitrogen relationships in leaves of C3 plants. Oecologia: 78: 9-19.

Faust, M., 1989. Physiology of Temperate Zone Fruit Trees. John Wiley and Sons. 634p.

Iezzoni, A. 2013. Sweet Cherry Fruit Size. http://www.extension.org/pages/66586/sweetcherry-fruit-size\#.UqcUn9Krrm4). (Accessed at June 2014).

Long, L.E., 2005.Turkey: The Sleeping Giant Awakens. http://extension.oregonstate.edu/wasco/sites/default/ files/horticulture/cherries_around_world/documents/ GFGTurkey05.pdf.( accessed at May, 2014).

Long, L.E., 2006. Turkish Cherries or a Rose by Any Other Name, http: extension.oregonstate.edu/.../ Turkish Cherries. (Accessed at: November, 2013).

Ouzounis, T. Lang, G.A. 2011. Foliar Applications of Urea Affect Nitrogen Reserves and Cold Acclimation of Sweet Cherries (Prunus avium L.) on Dwarfing Rootstocks. HortScience 146(7): 10151021.

Rothwell, N. 2012. Fall foliar nitrogen applications should be applied now in cherries http://msue.anr.msu.edu/news/fall_foliar_nitrogen_a pplications_should_be_applied_now_in_cherries. (Accessed at: September, 2013).

Tukey, H. B. 1952. The uptake of Nutrients By Leaves and Bark of Fruit Trees. 13th International Hort. Congress, pp. 9.

Xu, Z., Yuan-mao, J., Fu-tian, P., Xiang-kui, Z., Yan-ju, L., Deng-chao, Z., 2007. Studies on Characteristics of the Absorption, Distribution and Utilization of Foliar Application of $\sim(15) \mathrm{N}$-Urea in 'Hongdeng' Sweet Cherry. Plant Nutrition and Fertilizer Science. 13(4): 684 